\title{
In vivo DNA damaging and apoptotic potential of silver nanoparticles in Swiss albino mice
}

\author{
This article was published in the following Dove Press journal: \\ OncoTargets and Therapy \\ 29 January 2015 \\ Number of times this article has been viewed
}

\author{
Mohammed A Al Gurabi \\ Daoud Ali \\ Saad Alkahtani \\ Saud Alarifi \\ Department of Zoology, College \\ of Science, King Saud University, \\ Riyadh, Saudi Arabia
}

Correspondence: Daoud Ali

Department of Zoology, College of Science, BOX 2455, King Saud University, Riyadh II45I, Saudi Arabia

Tel +96655890 4621

Fax +4678514

Email daudali.ksul2@yahoo.com; aalidaoud@ksu.edu.sa

\begin{abstract}
Nanoparticles can potentially cause adverse effects on organs, tissue, cell levels, and protein levels because of their physicochemical properties. Silver nanoparticles (AgNPs) are being used on a wide scale in world consumer markets; their potential hazards for humans remain largely unknown. This study aimed to investigate the intraperitoneal toxicity of AgNPs (26 mg per kg of body weight, $52 \mathrm{mg}$ per $\mathrm{kg}$ of body weight, and $78 \mathrm{mg}$ per $\mathrm{kg}$ of body weight) over 72 hours in Swiss albino mice. AgNPs induced a significant increase in serum liver injury markers including alkaline phosphatase, alanine aminotransferase, and aspartate aminotransferase. Induction of DNA damage was also studied in mice injected with AgNPs. Apoptosis (detected by using the terminal deoxynucleotidyl transferase deoxyuridine triphosphatase nick end labeling assay method) in liver tissue and DNA strand breaks (detected by using the comet assay method) in lymphocytes revealed that a concentration of $78 \mathrm{mg}$ of AgNPs per $\mathrm{kg}$ body weight can cause significant apoptosis and DNA damage. The DNA damage and apoptosis raise the concern about the safety associated with application of the AgNPs. Significantly more alterations were induced in the hepatocytes of animals exposed to AgNP doses than in the control animals. The induced histological and apoptotic changes may be due to AgNP toxicity. Immunohistochemical and ultrastructural of AgNP.
\end{abstract}

Keywords: silver nanoparticles, liver tissue, histology, apoptosis, DNA damage, Swiss albino mice

\section{Introduction}

Nanotechnology is a new field with prospective applications for domestic, industrial, and biomedical products. ${ }^{1}$ The increasing use of engineered nanomaterials in a variety of consumer products, such as health, cosmetic, food, agricultural, recreational, and clothing products, has afforded increasing exposure of human tissue and physiology to nanomaterials by different routes into the human body. The consequences of such exposure, both deliberate and inadvertent, to large populations are currently being debated with little consensus on risk, toxicity, risk management, and exposure. ${ }^{2}$ These properties need to be evaluated in order to provide a scientific basis for the safe development of nanotechnology. The unique properties of nanomaterials (chemical, mechanical, optical, magnetic, and biological) make them desirable for industrial and medical applications. ${ }^{3}$ Increasing systemic exposure to humans in dermally absorbed, ophthalmologically applied, ingested, inhaled, and possibly parenterally injected silver forms facilitates vascular transport and penetration of AgNPs across tissue surfaces and through membranes. Therefore, whether the potential for evasion of immune cell-based clearance will lead to systematic acute cytotoxicity, chronic cytotoxicity, or illness remains an open question. ${ }^{4}$ Oberdörster et $\mathrm{al}^{5}$ reported that nanoparticles are 
materials of great concern among health and environmental scientists because they are prospective human and environmental menaces.

The lethal properties of nanoparticles can be attributed to their small size and large surface area, both of which increase chemical reactivity in and penetration into the living cells. ${ }^{6}$ It has been reported that AgNPs are more toxic than other metal nanoparticles, including aluminum, iron, nickel, and manganese, but the mechanism of AgNP toxicity is not clear. ${ }^{7,8} \mathrm{Li}$ and $\mathrm{Chen}^{9}$ reported that nanoparticles crossed biological barriers to reach different organs because of the nanoparticles' small size and surface properties. Free radical production and oxidative stress provokes a wide variety of cellular events, including DNA damage and apoptosis. ${ }^{10}$

The aim of this study was to assess the biological risks and benefits of AgNPs. To achieve this, we undertook a systematic study (Figure 1) involving the evaluation of apoptosis, biochemical properties, and oxidative DNA damage. We studied the effect of acute dosing with AgNPs in order to identify potential ultrastructural alterations in the liver and blood parameters of the Swiss albino mice and to assess cellular responses when AgNPs are used in biomedical applications.

\section{Materials and methods}

\section{Chemicals and animals}

Silver nitrate (99.9\%), cetyltrimethylammonium bromide

(CTAB , 98\%) and propidium iodide were obtained from the
Sigma-Aldrich Co. (St Louis, MO, USA). All other chemicals were purchased from other commercial sources.

A total of 40 healthy Swiss albino mice were picked up from the Laboratory Animal Center (College of Pharmacy, King Saud University, Riyadh, Saudi Arabia). All of the mice were of nearly the same age (6 weeks old), and each weighed $25-30 \mathrm{~g}$.

\section{AgNP preparation and characterization}

AgNPs were prepared by the reduction of silver nitrate solution with aniline in the presence of CTAB. A series of experiments was performed in which variances were made in the concentrations of oxidant, reductant, and stabilizer in order to obtain a perfectly transparent silver solution. In a typical procedure, $8 \mathrm{~mL}$ of a $0.01 \mathrm{~mol} / \mathrm{dm}^{3}$ solution of silver nitrate was mixed with $5 \mathrm{~mL}$ of a $0.01 \mathrm{~mol} / \mathrm{dm}^{3} \mathrm{CTAB}$ solution. The colorless reaction mixture slowly converted to the characteristic pale yellow color when $20 \mathrm{~mL}$ of a $0.01 \mathrm{~mol} / \mathrm{dm}^{3}$ solution of aniline was added in the solution of silver nitrate and CTAB. The total volume of the reaction mixture was always $50 \mathrm{~mL}$. The whole solution had a $\mathrm{pH}$ of 10.2. The appearance of color indicated the formation of AgNPs. ${ }^{11}$

AgNPs were suspended in Milli-Q water at a concentration of $10 \mathrm{mg} / 10 \mathrm{~mL}$. The stock suspension was probe sonicated at $40 \mathrm{~W}$ for 15 minutes. The hydrodynamic size and zeta potential of the suspension of AgNPs in water were measured by dynamic light scattering (Zeta sizer-HT; Malvern Instruments, Malvern, UK). Samples for transmission electron microscopy

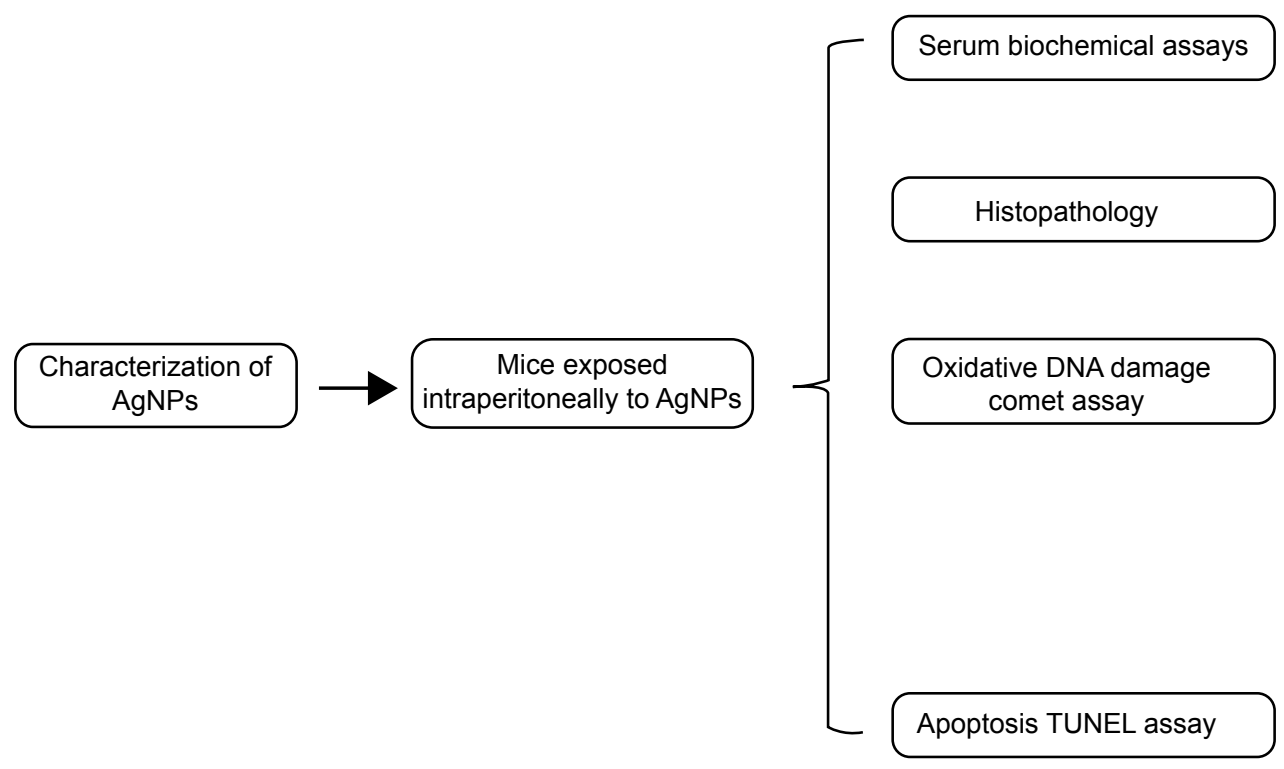

Figure I Schematic diagram of study design.

Abbreviations: AgNPs, silver nanoparticles; TUNEL, terminal deoxynucleotidyl transferase mediated deoxyuridine triphosphatase nick end labeling. 
(TEM) analysis were prepared by drop-coating carbon-coated copper TEM grids with AgNP solution. The films on the TEM grids were allowed to dry prior to measurement. TEM measurements were performed on a JEOL model 2100F instrument operated at an accelerating voltage at $200 \mathrm{kV}$.

\section{Experimental design}

The mice were maintained on standard laboratory rodent diet pellets and were housed in ventilated, humidity- and temperature-controlled cages on a 12 hours day/night cycle. Five animals from each group were killed by dislocation of the neck after 24 hours of treatment with AgNPs, and five more animals from each group were killed by the same method after 72 hours of treatment with AgNPs. All experiments were conducted in accordance with the guidelines approved by the King Saud University local animal care and use committee.

On the basis of a $50 \%$ of lethal concentration $\left(\mathrm{LC}_{50}\right)$ value of 72 hours, we have selected three doses $(26 \mathrm{mg} / \mathrm{kg}$ body weight, $52 \mathrm{mg} / \mathrm{kg}$ body weight, and $78 \mathrm{mg} / \mathrm{kg}$ body weight) of AgNPs. A study was conducted in order to compare the toxicity of nanoparticles with the three different doses after 24 hours of treatment and after 72 hours of treatment. The animals were divided into four groups of twenty mice each and treated for 72 hours as described in the next section.

Group I Control animals (received drinking water but no AgNPs).

Group II AgNPs (26 mg/kg body weight for 24 hours and 72 hours) were exposed via ip.

Group III AgNPs (52 mg/kg body weight for 24 hours and 72 hours) were exposed via ip.

Group IV AgNPs $(78 \mathrm{mg} / \mathrm{kg}$ body weight for 24 hours and 72 hours) were exposed via ip.

\section{Blood sampling}

Serum from the blood sample was harvested after centrifugation at 5,000 rotations per minute and stored at $-80^{\circ} \mathrm{C}$ until it was time to determine aspartate aminotransferase (AST), alanine aminotransferase (ALT), and alkaline phosphatase (ALP) levels by using a Cayman chemical kit.

\section{Alkaline single-cell gel electrophoresis}

The single-cell gel electrophoresis/comet assay was performed as a three-layer procedure with a slight modification in the way conventional microscopic slides were used. ${ }^{12,13}$ The slides were cleaned with $100 \%$ ethanol and flame dried. The lymphocytes were separated from the whole blood by using the Histopaque density gradient centrifugation method.
The cells were diluted 20-fold for the comet assay. Viability of lymphocytes cells was evaluated by the trypan blue exclusion test method, and samples showing cell viability more than $84 \%$ were further processed for the comet assay. ${ }^{14}$ About $15 \mu \mathrm{L}$ of cell suspension (approximately 20,000 cells) was mixed with $85 \mu \mathrm{L}$ of $0.5 \%$ low-melting point agarose and layered on one end of a frosted plain glass slide that had been previously coated with a $200-\mu \mathrm{L}$ layer of normal agarose (1\%). Finally, the slide was covered with a third layer of $100 \mu \mathrm{L}$ of low-melting point agarose. After the solidification of the gel, the slides were immersed in lysing solution (2.5 M NaCl, $100 \mathrm{mM}$ disodium ethylenediaminetetraacetic acid [ $\mathrm{Na}_{2}$ EDTA], $10 \mathrm{mM}$ Tris $\mathrm{pH} 10$ with $10 \%$ dimethyl sulfoxide, and 1\% Triton X-100 freshly added) overnight at $4^{\circ} \mathrm{C}$. The slides were then placed in a horizontal gel electrophoresis unit, immersed in fresh cold alkaline electrophoresis buffer (300 mM NaOH, $1 \mathrm{mM} \mathrm{Na}{ }_{2}$ EDTA, and $0.2 \%$ dimethyl sulfoxide, $\mathrm{pH}>13.5$ ), and left in solution for 20 minutes at $4{ }^{\circ} \mathrm{C}$ for DNA unwinding and conversion of alkali-labile sites to single strand breaks. Electrophoresis was carried out by using the same solution at $4^{\circ} \mathrm{C}$ for 20 minutes at $15 \mathrm{~V}(0.8 \mathrm{~V} / \mathrm{cm})$ and $300 \mathrm{~mA}$. The slides were neutralized by washing them three times with $0.4 \mathrm{M}$ Tris buffer at a $\mathrm{pH}$ of 7.5 to remove excess alkali, and then they were stained with $75 \mu \mathrm{L}$ ethidium bromide for 5 minutes to visualize DNA damage. As a positive control, the liver cells were treated ex vivo with $100 \mu \mathrm{M} \mathrm{H}_{2} \mathrm{O}_{2}$ for 10 minutes at $4^{\circ} \mathrm{C}$. Two slides per specimen were prepared ( 25 cells per slide, which is equivalent to 250 cells per unit of concentration). The slides were randomly scored by using an image analysis system (Komet-5.5; Kinetic Imaging Ltd., Liverpool, England) attached to a fluorescent microscope (Leica Microsystems, Wetzlar, Germany) equipped with appropriate filters. The parameter selected for quantification of DNA damage was percent tail DNA (percent tail DNA $=100 \%$ - percent head DNA), as determined by the software.

\section{Staining for apoptosis}

By using the manufacturer's specified protocol, paraffinembedded sections of liver tissue of control mice, mice treated with AgNPs over 24 hours, and mice treated with AgNPs over 72 hours were stained for apoptotic nuclei by using the terminal deoxynucleotidyl transferase mediated deoxyuridine triphosphatase nick end labeling (TUNEL) assay (GenScript USA Inc., Piscataway, NJ, USA). Two slides from each group were manually quantitated for the total number of cells and for apoptotic cells within the liver tissue. Photographs were taken by using an optical microscope 
(Olympus Microscope BX51 with Digital Camera; Olympus Corporation, Tokyo, Japan).

\section{Histopathology}

As previously mentioned, Swiss albino mice were treated with intraperitoneal doses of AgNPs for either 24 hours or for 72 hours. After treatment, the mice were sedated and euthanized by decapitation. Fresh portions of the lateral lobes of the liver from each mouse were cut rapidly, fixed in neutral buffered formalin (10\%), then serially dehydrated with different grades of ethanol $(70 \%, 80 \%, 90 \%, 95 \%$ and $100 \%$ ). Dehydration was followed by clearing the samples in two changes of xylene. Samples were impregnated with two changes of molten paraffin wax, then embedded and blocked out. Paraffin sections (4-5 $\mu \mathrm{m})$ were stained with hematoxylin and eosin by using the conventional histological and staining method. ${ }^{15}$ Stained sections of control and treated mice were observed, and the photos were taken by using the optical microscope to view alterations in the architecture, the hepatocytes, and the sinusoids and to detect the presence of degeneration, necrosis, fatty change, and portal fibrosis.

\section{Statistical analysis}

At least three independent experiments were carried out for each evaluation. Results were expressed as mean \pm standard error of mean (SEM) and statistically analyzed by one-way analysis of variance (ANOVA). A $P$-value of less than 0.05 was considered statistically significant.

\section{Results and discussion}

The size and shape of AgNPs were seen by TEM and observed in nano range, but the AgNPs made small agglomerates in aqueous suspension. The average size measured by TEM was

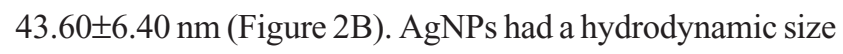
of around $189 \mathrm{~nm}$, and their zeta potential was $-23.8 \mathrm{mV}$. The physicochemical effects of nanoparticles come from their high surface area to volume ratio. Nanoparticles have a higher fraction of atoms on their surfaces than do microparticles; this property makes nanoparticles more reactive.

The main outcome of this study was that significantly greater levels $(P>0.05)$ of ALP, ALT, and AST were seen in mice treated with $26 \mathrm{mg}$ AgNPs per kg body weight, $52 \mathrm{mg}$ AgNPs per kg body weight, and $78 \mathrm{mg}$ AgNPs per kg body weight than were seen in the control mice. The comparison between the mice exposed to AgNPs and those used as controls is shown in Figure 3. An initial step in measuring liver damage is a simple blood biochemical test to evaluate the presence of certain liver enzymes in the blood. The activity of these enzymes is normally used to determine liver function. Under normal conditions, these enzymes reside within the hepatocytes. But when the liver is injured, these enzymes are spilled in to blood stream.

Among the most sensitive and widely used of hepatic enzymes are AST and ALT. These enzymes are normally found within hepatic cells. If the liver is damaged, the liver cells spill into blood. The levels of enzymes are higher in cases of hepatic cell death resulting from shock or from drug or nanoparticle toxicity. ${ }^{16}$ As a result, the rate at which AgNPs are metabolized in the liver is believed to be dependent upon the injected dose and time. ALP, ALT, and AST levels are indicative of the functional efficacy of the liver and are very sensitive to all disease processes of the liver. The histological fluctuations perceived in the liver and the associated increases in ALP, ALT, and AST levels indicate compromised liver function. Apoptosis and DNA damage were seen in liver cells and lymphocytes of mice treated with

B

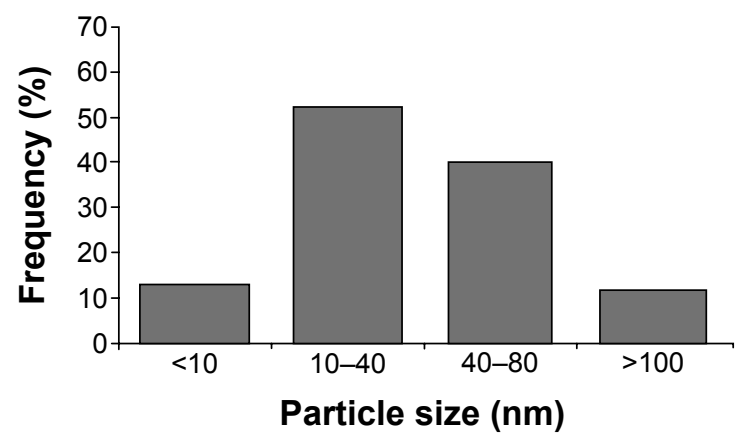

Figure 2 Characterization of the AgNPs.

Notes: TEM image of the particles (A). The size distribution histogram generated by using a TEM image (B).

Abbreviations: AgNPs, silver nanoparticles; TEM, transmission electron microscopy. 
A

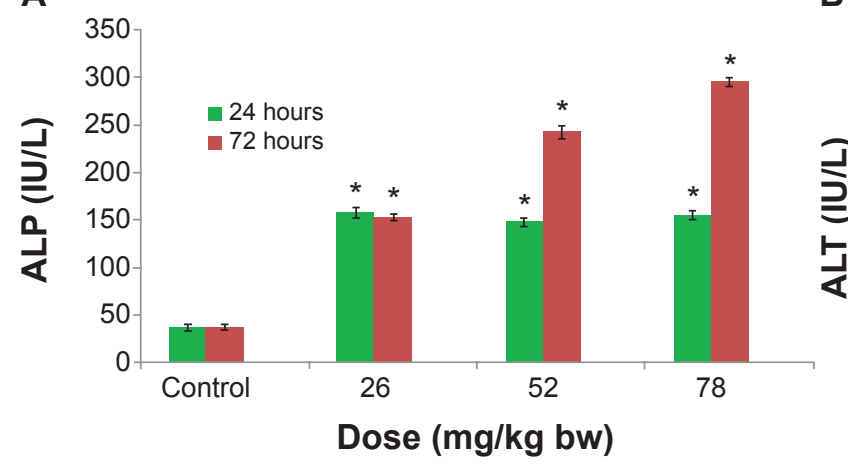

B

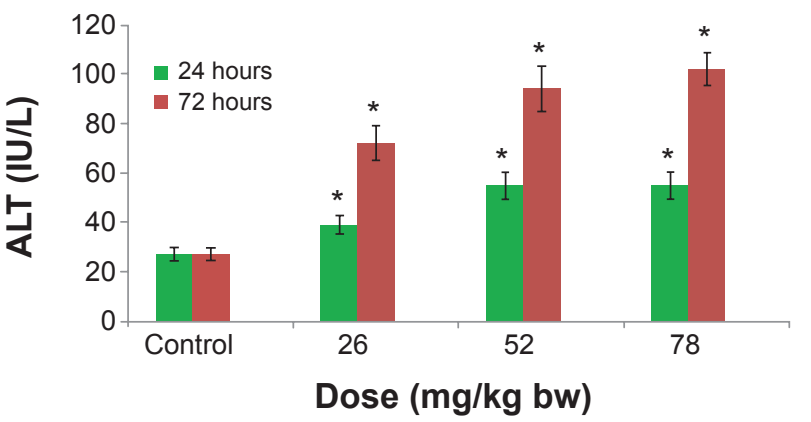

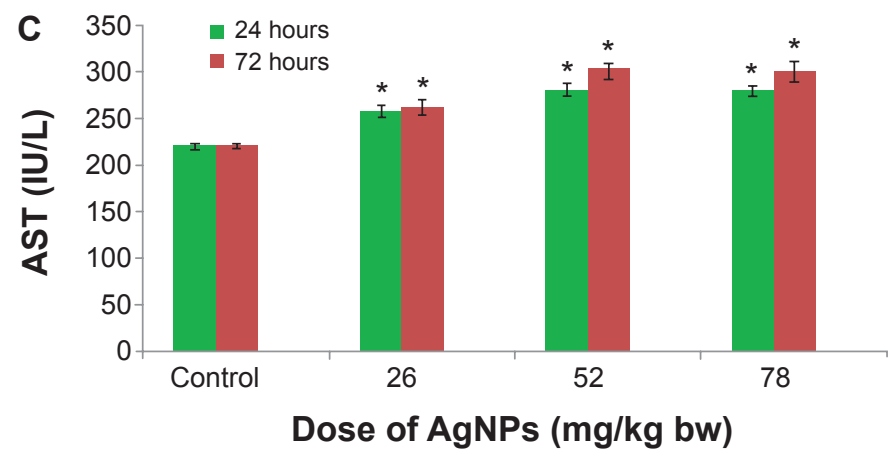

Figure 3 Levels of enzymes that indicate liver function after exposure to AgNPs.

Notes: Levels of ALP (A), ALT (B), and AST (C) in liver tissue samples of Swiss albino mice after exposure to AgNPs for 24 hours and for 72 hours. Each value represents the mean \pm SEM of three experiments. $* P<0.05$ indicates a statistically significant higher concentration of substance in mice exposed to AgNPs than in control mice.

Abbreviations: ALP, alkaline phosphatase; ALT, alanine aminotransferase; AST, aspartate aminotransferase; IU, international units; bw, body weight; AgNPs, silver nanoparticles; SEM, standard error of mean.

AgNPs (Figures 4 and 5). Greater histological variations were noticed in the liver tissue samples of Swiss albino mice treated with AgNPs than in those of the control group (Figure 6). Histopathological observation showed AgNPs caused severe damage in the liver. Damaged liver cells develop leaky membranes, which allowed for the leakage of intracellular enzymes into the blood stream. ${ }^{17}$ In the present study, Kupffer cells may be more efficient at metabolizing AgNPs than are the liver endothelial cells. The difference between the rates of metabolism in these cells is believed to be dependent upon the differences in concentrations of AgNPs taken by the various cell types. ${ }^{18}$ Johar et a ${ }^{19}$ reported that AgNPs interact with proteins and enzymes in the interstitial tissue of the liver; this reaction prevents the antioxidant protection mechanism and leads to the production of reactive oxygen species, which in turn may initiate an inflammatory response.

Alteration and growth of liver cells with the stretching of the central vein and blood sinusoids show that AgNPs may disturb the permeability of the cell membranes of liver cells and of the endothelial lining of blood vessels. Enlargement of liver cells that have been treated with AgNPs, as seen with the growth of liver cells that were treated nanoparticles in another study ${ }^{20}$ and as seen in our study, may lead to the adaptation of cell transporters. Binucleation is a concern related to cell injury, and a type of chromosomal hyperplasia is typically observed in redeveloping cells. ${ }^{21}$ Cell puffiness may be accompanied by the escape of lysosomal hydrolytic enzymes and thereby may lead to the deterioration of the cytoplasm and macromolecules..$^{22}$ Hydropic disintegration is a result of ion and fluid homeostasis and leads to an increase in intracellular water. ${ }^{23}$ The vacuole-related swelling seen in the cytoplasm of liver cells from mice exposed to AgNPs indicates acute liver injury.

We also observed that DNA damage and apoptosis in liver cells of mice treated with AgNPs increased in a doseand time-dependent manner (Figures 4 and 5). Sporadic, spotty, and well defined areas of necrosis were also noticed in some liver cells from mice treated with AgNPs; this was due to oxidative stress. AgNPs have been shown to induce apoptosis and genotoxicity in plants (Allium cepa and Nicotiana tabacum) and in animals (Swiss albino mice). ${ }^{24}$ In the current study, after intraperitoneal exposure of AgNPs (78 $\mathrm{mg}$ per kg body weight), the difficulty encountered in clearance of these nanoparticles resulted in deposition of 

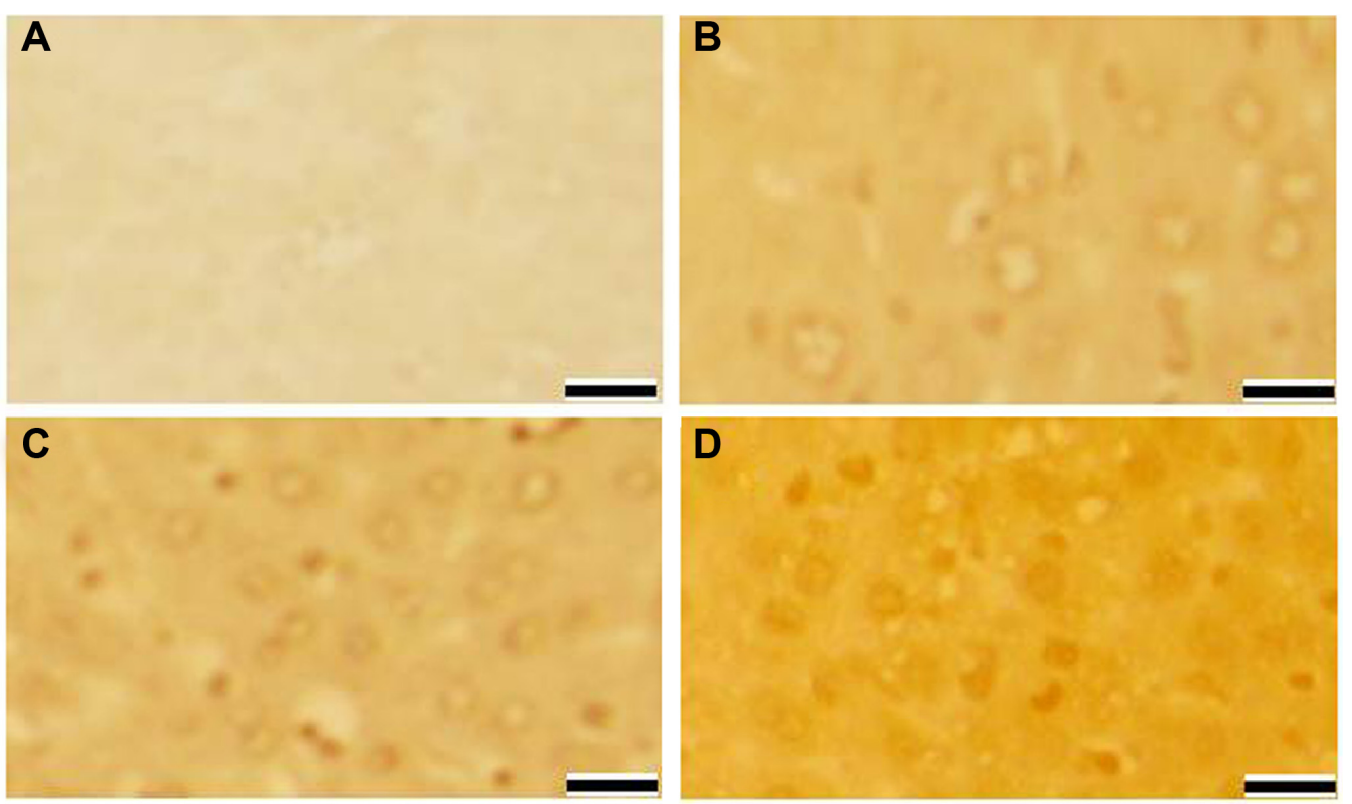

Figure 4 Liver cell apoptosis after 72 hours of exposure to AgNPs.

Notes: Apoptosis of cells in liver tissue of Swiss albino mice after exposure to AgNPs over 72 hours. Control (A); 26 mg AgNPs per kg bw (B); 52 mg AgNPs per kg bw (C); and $78 \mathrm{mg}$ AgNPs per kg bw (D). Scale bar (D) $20 \mu \mathrm{m}$.

Abbreviations: AgNPs, silver nanoparticles; bw, body weight.
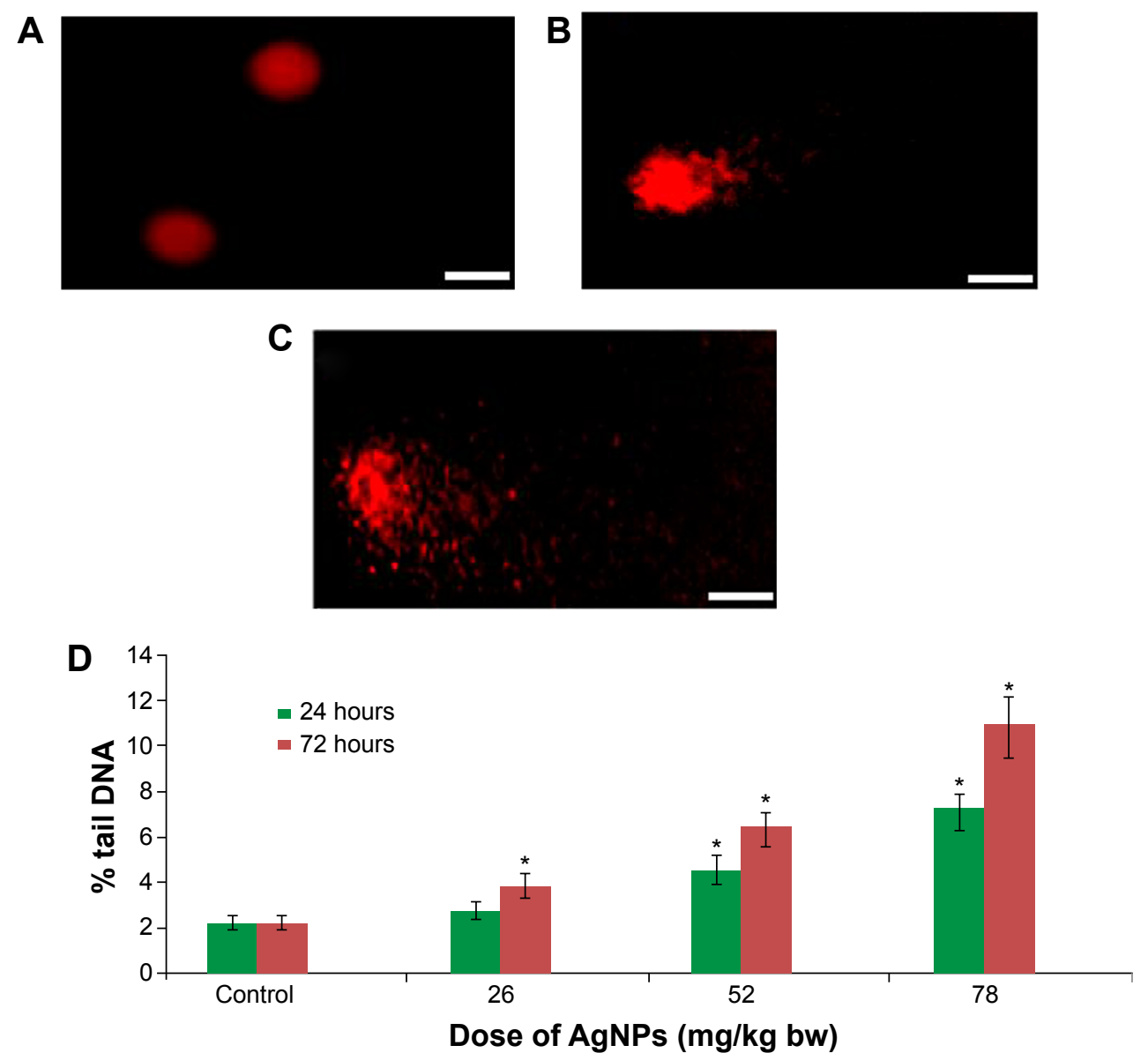

Figure 5 DNA damage in lymphocytes of Swiss albino mice after exposure to AgNPs.

Notes: Control (A); 78 mg AgNPs per kg bw for 24 hours (B); and 78 mg AgNPs per kg bw for 72 hours (C). Percent tail DNA. Data are presented as mean \pm SEM of three experiments (D). $* P<0.05$ indicates statistically significant difference with respect to the control. Scale bar $(\square) 20 \mu \mathrm{m}$.

Abbreviations: AgNPs, silver nanoparticles; bw, body weight; SEM, standard error of mean. 
A

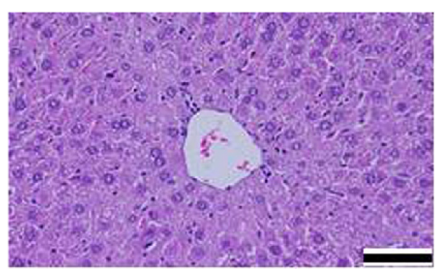

B

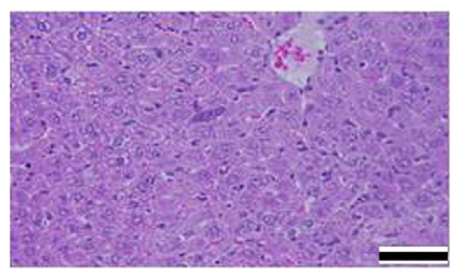

C

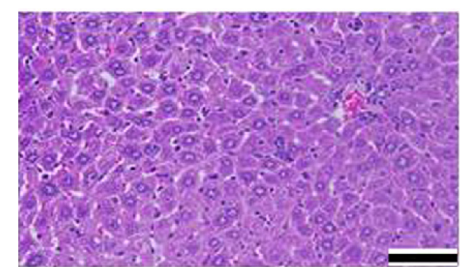

D

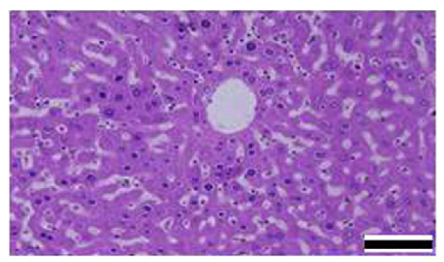

E

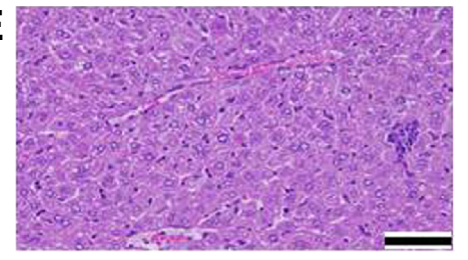

$\mathbf{F}$

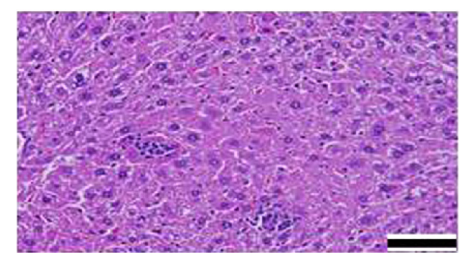

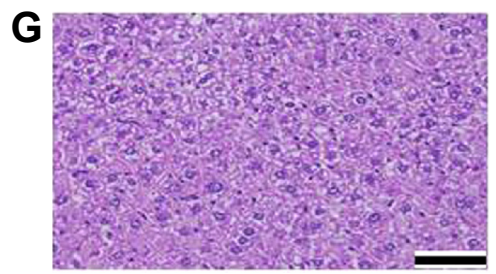

Figure 6 Microphotographs of hematoxylin and eosin stained liver tissue.

Notes: Mice injected with Milli-Q water demonstrated normal histological architecture after 72 hours of treatment (A). Mice injected with AgNPs (26 mg/kg bw) demonstrated lymphocyte infiltration in the hepatic portal space after 24 hours of treatment (B). Mice injected with AgNPs (52 mg/kg bw) demonstrated marked necrosis and scattered hemorrhages after 24 hours of treatment (C). Mice injected with AgNPs (78 mg/kg bw) demonstrated vacuolization of hepatocytes after 24 hours of treatment (D). Mice injected with AgNPs (26 mg/kg bw) demonstrated edema around the blood vessel after 72 hours of treatment (E). Mice injected with AgNPs (52 mg/kg bw) demonstrated binucleation of hepatocytes and lymphocytic infiltration after 72 hours of treatment (F). Mice injected with AgNPs (78 mg/kg bw) demonstrated swelling and hydropic degeneration of hepatocytes after 72 hours of treatment $(\mathbf{G})$. All scale bars $(\square) 50 \mu \mathrm{m}$. All image magnifications are $100 \times$.

Abbreviations: AgNPs, silver nanoparticles; bw, body weight.

particles in the liver and caused hepatic lesions. The liver, which is the main detoxification organ in the body, is activated to eliminate the side effects induced by the ingested mass of AgNPs; a portion of these nanoparticles should be excreted by the kidney. Because of their small size and the difficulty in their clearance, AgNPs stayed in the animals; hepatic damage happened after intraperitoneal treatment because of the high concentration of AgNPs.

In conclusion, our results indicate that in Swiss albino mice, AgNPs induce apoptosis, histological changes in liver tissue, and genotoxictiy in lymphocytes. More histochemical and ultrastructure investigations are needed to correlate these types of damage with the therapeutic and diagnostic uses of AgNPs.

\section{Acknowledgment}

The authors would like to extend their sincere appreciation to the Deanship of Scientific Research at King Saud University for funding this research group (RG-1436-180).

\section{Disclosure}

The authors report no conflicts of interest in this work.

\section{References}

1. Peralta-Videa JR, Zhao L, Lopez-Moreno ML, de la Rosa G, Hong J, Gardea-Torresdey JL. Nanomaterials and the environment: a review for the biennium 2008-2010. J Hazard Mater. 2011;186(1):1-15.

2. Johnston HJ, Hutchison G, Christensen FM, Peters S, Hankin S, Stone V. A review of the in vivo and in vitro toxicity of silver and gold particulates: particle attributes and biological mechanisms responsible for the observed toxicity. Crit Rev Toxicol. 2010;40(4):328-346.

3. Nel A, Xia T, Mädler L, Li N. Toxic potential of materials at the nano level. Science. 2006;311(5761):622-627.

4. Atiyeh BS, Costagliola M, Hayek SN, Dibbo SA. Effect of silver on burn wound infection control and healing: review of the literature. Burns. 2007;33(2):139-148.

5. Oberdörster G, Oberdörster E, Oberdörster J. Nanotoxicology: an emerging discipline evolving from studies of ultrafine particles. Environ Health Perspect. 2005;113(7):823-839.

6. PEN 2009 [webpage on the Internet]. Washington, DC: Project of the Emerging Nanotechnologies (PEN); 2014. Available from: http://www. nanotechproject.org. Accessed January 20, 2015.

7. Braydich-Stolle L, Hussain S, Schlager JJ, Hofmann MC. In vitro cytotoxicity of nanoparticles in mammalian germline stem cells. Toxicol Sci. 2005;88(12):412-419.

8. Tang J, Xi T. Status of biological evaluation on silver nanoparticles. Sheng Wu Yi Xue Gong Cheng Xue Za Zhi. 2008; 25(4):958-961.

9. Li YF, Chen C. Fate and toxicity of metallic and metal-containing nanoparticles for biomedical applications. Small. 2011;7(21): 2965-2980.

10. Ostrovsky S, Kazimirsky G, Gedanken A, Brodie C. Selective cytotoxic effect of $\mathrm{ZnO}$ nanoparticles on glioma cells. Nano Res. 2009;2(11): 882-890. 
11. Sharma VK, Yngard RA, Lin Y. Silver nanoparticles: green synthesis and their antimicrobial activities. Advances in Colloidal and Interface Sciences. 2009;145(1):83-96.

12. Singh NP, McCoy MT, Tice RR, Schneider EL. A simple technique for quantization of low levels of DNA damage in individual cells. Exp Cell Res. 1988;175(1):184-191.

13. Ali D, Nagpure NS, Kumar S, Kumar R, Kushwaha B. Genotoxicity assessment of acute exposure of chlorpyrifos to freshwater fish Channa punctatus (Bloch) using micronucleus assay and alkaline single-cell gel electrophoresis. Chemosphere. 2008;71(10):1823-1831.

14. Anderson D, Yu TW, Phillips BJ, Schmerzer P. The effect of various antioxidants and other modifying agents on oxygen-radical-generated DNA damage in human lymphocytes in the COMET assay. Mutat Res. 1994;307(1):261-271.

15. Alarifi S, Ali D, Al-Doaiss AA, Ali BA, Ahmed M, Al-Khedhairy AA. Histologic and apoptotic changes induced by titanium dioxide nanoparticles in the livers of rats. Int J Nanomedicine. 2013;8: 3937-3943.

16. Sally A, Tice RPH, Dean Parry RPH. Medications that need hepatic monitoring. Hospital Pharmacy. 2001;36(4):456-464.

17. Green RM, Flamm S. AGA technical review on the evaluation of liver chemistry tests. Gastroenterology. 2002;123(4):1367-1384.
18. Wisse E, Doucet D, Van Bossuyt H. A transmission electron microscopic study on the uptake of AMI-25 by sinusoidal liver cells. In: Wisse E, editor. Cells of the Hepatic Sinusoid. Netherlands: Kupffer Cell Foundation; 1991:534-539.

19. Johar D, Roth JC, Bay GH, Walker JN, Kroczak TJ, Los M. Inflammatory response, reactive oxygen species, programmed (necrotic-like and apoptotic) cell death and cancer. Rocz Akad Med Bialymst. 2004;49: 31-39.

20. Johnson CE. Effects of fluid imbalances. In: Conn MP, editor. Neurosciences in Medicine. New York: JB Lippincott Company; 1995. 187-189.

21. Gerlyng P, Åbyholm A, Grotmol T, et al. Binucleation and polyploidization patterns in developmental and regenerative rat liver growth. Cell Prolif. 1993;26(6):557-565.

22. Del Monte U. Swelling of hepatocytes injured by oxidative stress suggests pathological changes related to macromolecular crowding. Med Hypotheses. 2005;64(4):818-825.

23. Schrand AM, Rahman MF, Hussain SM, Schlager JJ, Smith DA, Syed AF. Metal-based nanoparticles and their toxicity assessment. Wiley Interdiscip Rev Nanomed Nanobiotechnol. 2010;2(5):544-568.

24. Ghosha M, Manivannan J, Sinha S, et al. In vitro and in vivo genotoxicity of silver nanoparticles. Mutat Res. 2012;749(1-2):60-69.
OncoTargets and Therapy

\section{Publish your work in this journal}

OncoTargets and Therapy is an international, peer-reviewed, open access journal focusing on the pathological basis of all cancers, potential targets for therapy and treatment protocols employed to improve the management of cancer patients. The journal also focuses on the impact of management programs and new therapeutic agents and protocols on

\section{Dovepress}

patient perspectives such as quality of life, adherence and satisfaction. The manuscript management system is completely online and includes a very quick and fair peer-review system, which is all easy to use. Visit http://www.dovepress.com/testimonials.php to read real quotes from published authors. 